\title{
Variscan ophiolite belts in the Ossa-Morena Zone (Southwest Iberia): Geological characterization and geodynamic significance
}

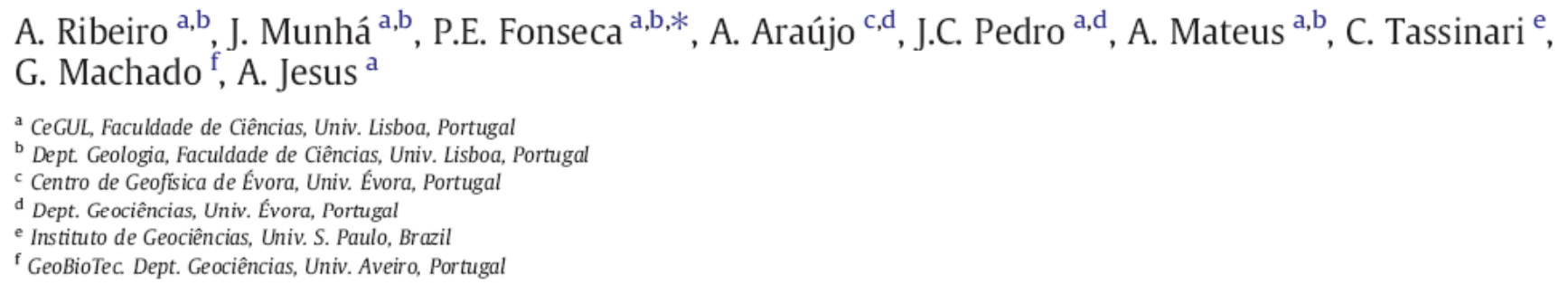

\section{A R T I C L E I N F O}

\section{Article history:}

Received 31 May 2009

Received in revised form 14 September 2009

Accepted 21 September 2009

Available online 4 October 2009

\section{Keywords:}

Ophiolite belts

Geodynamic evolution

SW lberian Variscides

\begin{abstract}
A B S T R A C T
The boundary between the Iberian and South-Portuguese terranes in SW Iberia is traced by a suture recording the closure of Rheic and related oceans through NNE-directed subduction. The western segment of the suture comprises imbrications of the Iberian Terrane Relative Autochthon (Neoproterozoic - Lower Palaeozoic) and Allochthonous Complexes. The Iberian Terrane Relative Autochthon is overlain by Lower-Middle Devonian metasediments and an unconformable cover of Lower Carboniferous (calc-alkaline) Volcano-sedimentary Complexes, both preserving evidence of very-low grade metamorphism. The Allochthonous Complexes include disrupted slivers of eclogite (ca. $370 \mathrm{Ma}$ ), klippen and slices of an internal ophiolite sequence (IOMZOS), a basal tectonic mélange (Moura Phyllonitic Complex) and an external ophiolite (Beja-Acebuches Complex, BAOC). A large layered gabbroic sequence (LCS), whereas part of the Beja Igneous Complex, intruded (ca. 350-340 Ma) the SW suture domains. The IOMZOS represents obducted remnants of the Rheic Ocean, for which available SHRIMP U-Pb data indicate an age of $479 \pm 5 \mathrm{Ma}$. This ocean, which separated Iberia from a promontory of Gondwana and Avalonia (now represented by the South-Portuguese Terrane), opened near the Cambrian-Ordovician boundary through a "rift-jump" from an intra-cratonic setting (within the Iberian Terrane) to oceanic rifting. The BAOC displays geochemical features compatible with derivation from a shortlived back-arc basin (?Lower-Middle Devonian; $\mathrm{T}_{\mathrm{DM}}(\mathrm{Sm}-\mathrm{Nd}) \sim 380-440 \mathrm{Ma}$ ). The Variscan ophiolite belts preserved along the SW Variscides were emplaced by antithetic obduction in two stages, both with shearing sense towards the NNE. The first stage, which involved IOMZOS cold obduction, exhumed HP-rocks (ca. $370 \mathrm{Ma}$ ) and created a foreland bulge towards the Iberian Terrane's SW flank; this mechanism controlled the development of the volcanic-related carbonate shelves and the contemporaneous Terena flysch trough to the NE. The second stage corresponds to BAOC hot obduction, carrying the IOMZOS klippen in piggy-back style and affecting the southern margin of the LGS at ca. 350-340 Ma.
\end{abstract}

(C) 2009 International Association for Gondwana Research. Published by Elsevier B.V. All rights reserved. 